\title{
Status of the polecat Mustela putorius (Linnaeus, 1758) in France and management implications
}

\author{
Status del turón Mustela putorius (Linnaeus, 1758) \\ en Francia e implicaciones para su gestión

\section{Mustela putorius (Linnaeus, 1758) ipurtatsaren estatusa Frantzian eta kudeaketarekin lotutako inplikazioak}

\author{
Rachel Berzins ${ }^{1 *}$, Sandrine Ruette ${ }^{2}$ \\ 1 DIROM ONCFS \\ 2 ONCFS - CNERA PAD \\ *Corresponding author: rachel.berzins@oncfs.gouv.fr
}

\begin{abstract}
The polecat Mustela putorius Linnaeus, 1758 is an elusive species whose lifestyle is relatively unknown. In France, the species might be legally hunted. Knowledge of the distribution of the species on the national scale is a necessary prerequisite for the implementation of appropriated management and conservation measures. The National Wildlife and Hunting Agency (ONCFS) has developed a method for collecting data at the national scale so that to create presence maps of small and medium-sized carnivores. The presence map of the polecat is presented in this note, based on data collected from 2001 to 2010. The map shows that the species is fairly well distributed throughout the country with the exception of some regions that deserve further study. According to current knowledge, the factors threatening the polecat in France are above all the deep modifications of the preferential habitats of the polecat, particularly the important decrease of wetlands and hedged farmland; the increase of the road network and the poor state of rabbit Oryctolagus cuniculus (Linnaeus, 1758) populations, an important food resource notably in the Mediterranean regions. The importance of secondary rodenticide poisoning needs to be evaluated. We postulated that trapping is not nowadays a major threat to the species in France. Management and conservation measures of its habitat through the implementation of public policies could favor its maintenance.
\end{abstract}

KEY WORDS: Conservation, Distribution, European polecat, France, Threats.

\section{RESUMEN}

El turón Mustela putorius Linnaeus, 1758 es una especie huidiza de costumbres poco conocidas. Su caza en Francia podriar estar permitida. Conocer la distribución del Turón en territorio nacional es indispensable para tomar medidas de gestión y de conservación apropiadas a su estatus. La Oficina Nacional de Caza y Fauna Salvaje (ONCFS) ha desarrollado un método de recogida de datos a escala nacional con el fin de realizar mapas de presencia de pequeños y medianos carnívoros. En este artículo, se muestra el mapa de presencia del Turón obtenido a partir de los datos recogidos del año 2001 al 2010. Éste, indica que la especie está bien distribuida en el territorio a excepción de algunas regiones que merecerían un más estudios. Basándonos en los conocimientos actuales, los factores que amenazan al Turón en Francia son sobre todo las enormes modificaciones de su hábitat, particularmente una disminución importante de los humedales y de las zonas boscosas; el aumento de la red de carreteras y el mal estado de ciertas poblaciones de conejos Oryctolagus cuniculus (Linnaeus, 1758), importante fuente alimenticia, especialmente en las regiones mediterráneas. La gestión y la conservación del hábitat del Turón a través de la realización de políticas públicas serían unas medidas que podrían favorecer el mantenimiento de esta especie.

PALABRAS CLAVE: Conservación, Distribución, Turón, Francia, Amenazas.

\section{LABURPENA}

Mustela putorius Linnaeus, 1758 ipurtatsa oraindik ere ohitura ezezagunak dituen espezie iheskorra da da. Frantzian ehizatzea baimenduta egon daiteke. Ipurtatsak lurralde nazionalean duen banaketa ezagutzea ezinbestekoa da estatusaren araberako kudeaketako eta kontserbazioko neurriak adostu ahal izateko. Ehiza eta Fauna Basatiaren Bulego Nazionalak eskala nazionalean datuak jasotzeko metodoa garatu du haragijale txiki eta ertainen presentziari dagokien mapak prestatu ahal izateko. Artikuluan ipurtatsaren presentziaren mapa azaltzen da 2001 eta 2010 urteen artean jasotako datuetatik abiatuta. Mapan ikus daitekeenez, espeziea lurraldean ondo banatuta dago, ikerketa gehiago egin beharko litzatekeen eskualde batzuetan izan ezik. Egungo ezagutzak oinarritzat hartuta, Frantzian ipurtatsa mehatxatzen duten faktoreak honako hauek dira: batez ere, habitataren aldaketa handiak (bereziki, hezeguneek eta zonalde oihantsuek jasan duten jaitsiera handia); errepideen sarea handitu izana eta Oryctolagus cuniculus (Linnaeus, 1758) untxien populazio batzuek bizi duten egoera txarra (bereziki eskualde mediterraneoetan), hori baita ipurtatsaren elikadura-iturri nagusietako bat. Ipurtatsaren habitata politika publikoen bidez kudeatzea eta kontserbatzea litzateke espezieari bizirauten laguntzeko neurrietako bat.

GAKO-HITZAK: Kontserbazioa, banaketa, ipurtatsa, Frantzia, mehatxuak.

\section{INTRODUCTION}

Among carnivores, the mustelids family is one of the most poorly known (Schaller, 1996), but also one of the most threatened (Bright, 2000). Despite a large number of members present in France, they are poorly known and are not emblematic, except the otter Lutra lutra (Linnaeus, 
1758). In France, most of them (the pine marten Martes martes (Linnaeus, 1758), the stone marten Martes foina (Erxleben, 1777), the American mink Mustela vison (Schreber, 1777), the polecat Mustela putorius (Linnaeus, 1758) and the weasel Mustela nivalis Linnaeus, 1766) might be legally hunted, and could be trapped in some part of France until 2012. Their behavior, most of the time crepuscular and solitary, does not facilitate their study in their natural habitat and many aspects of their biology are still unknown. This is the case of the polecat, whose status is judged worrying by some associations of nature protection. Various factors might threaten the polecat in France, as in Europe. The deep modifications of the preferential habitats of the polecat, particularly the important decrease of wetlands and hedged farmland are the mentioned in literature (Roger et al., 1988; Birks \& Kitchener, 1999; Baghli, 2003). The increase of the road network (Birks, 2000; Ruette et al., 2008), the poor state of rabbit Oryctolagus cuniculus (Linnaeus, 1758) populations, an important food resource notably in the Mediterranean regions, and secondary rodenticide poisoning (Shore et al., 1996; Birks, 1998; Shore et al., 1999; Shore et al., 2003; Fournier-Chambrillon et al., 2004) are also important threats but their impacts on populations needs to be evaluated. In France, studies on this species have focused on its diet (Lodé, 1991; Roger, 1991), its habitat use in relation to available resources (Lodé, 1994; Lodé, 1999) and its use of space (Lodé, 1993; Lodé, 1996). Although this information is essential to a better knowledge of the species biology, its distribution throughout the national territory remains an important prerequisite not only for the implementation of appropriated management and conservation measures but also to evaluate the conservation status of the species both at the national and European scale. Indeed, the species is listed in annex $V$ of the Habitat directive, i.e "animal species of Community interest whose taking in the wild and exploitation may be subject to management measures" (European Council 1992). Various methods to assess the presence and even the density (Gros et al., 1996; Balme et al., 2003; Maffei et al., 2005) of small and large carnivores have been tested and compared (Barea-Azcon et al., 2006; Gompper et al., 2006; Long et al., 2007). However, most of them can only be applied at the scale of a study area, because of the cumbersome implementation protocols.

The aim of this work is to present the latest distribution of the polecat in France, based on a methodology developed by the National Hunting and Wildlife Agency (ONCFS) since 2001 (Ruette et al., 2008). We discuss possible limitations of such a method. We then describe the potential threats and needs in term of conservation in France in the light of current knowledge of the species.

\section{MATERIAL AND METHODS}

The methodology developed by the ONCFS refines results based on inquiries (Ruette et al., 2004). Most often, inquiries at a large spatial scale are based on interviews (Gros, 1998; Gros, 2002) or volunteers involvement (Sewell et al., 2010; Bonardi et al., 2011) so that both the trai- ning of participants, their recognition skills and the time devoted to the inquiries can hardly if not be standardized. The wildlife protection officers are professionals of hunting and environmental police regulations, officially designated as agents who are commissioned by the Minister of Ecology and, as such, may intervene as sworn expert witnesses. Thus, they are trained to the recognition of species. There are around 1000 wildlife protection officers on the field, whose work implies the survey of territories for environmental and hunting policy on all the territory all the year round. This large distribution of trained professionals represents a good opportunity to collect reliable observations on small and medium carnivores all over the country, despite a heterogeneous road network according to regions and a variable observation effort between the officers. The method is based on a notebook put in each vehicle, in order to record all their observations of small and medium-sized carnivores, dead or alive, along with the date and the locality name (the locality is the smallest French administrative unit). Analysis of these notebooks provide a annual total number of observations of each species and allow to build a presence map at the national scale, each observation being located on a fixed grid of $10 \times 10 \mathrm{~km}$ of the European Agency of Environment (EAE).

We estimated the proportions of areas sampled by comparing locations of data collected for all species versus the polecat. We considered 21 regions in France, representing administrative areas of $25701 \pm 10775 \mathrm{~km}^{2}$ on average, excluding Corsica where the polecat has never been mentioned. We also compare our results to previous inquiries realized in 1998/1999 (Ruette et al., 2004, map available at $h$ ttp://carmen.carmencarto.fr/38/petits_carnivores.map) based on data gathered from the Departmental Associations of Trappers, the Departmental Federation of Hunters and the wildlife protection officers.

\section{RESULTS}

Between 2001 and 2010, all observations of small carnivores ( $n=79064)$ covered $53 \%$ of the localities and $100 \%$ of the territory on $10 \times 10 \mathrm{~km}$ EAE grid, for an annual average of 7900 observations. For the polecat, 7440 observations were recorded for an average of $744 \pm 176$ observations per year covering about $44 \%$ of the country (on the $10 \times 10 \mathrm{~km}$ grid). Polecat observations were collected in all regions in France except in Corsica. However, strong variations existed between regions (Table 1). Whereas percents of cells with at least one polecat observation (on the $10 \times 10 \mathrm{~km}$ EAE grid) are beyond $50 \%$ in most regions of north, east, west and center of France (regions 1 to 13 and 19 to 21, Fig. 1), observations were less frequent in south-west (regions 17 and 18) and even rare in south-east France (regions 14, 15 and 16). In the Alpines and Pyreneans mountains (in regions 14, 15, 17 and 18), the lower frequency of observations may be linked to the fact that polecat occurs up to $2000 \mathrm{~m}$ altitude. The lack of observations in the south-east part of France is probably linked to the scarce and irregular presence of the species in these regions. 


\begin{tabular}{|c|c|c|c|c|c|c|}
\hline & & & 2001-2010 period & & 1998-1999 inquiries & \\
\hline Name of the region & $\begin{array}{c}\text { Number } \\
\text { (see Fig. 1) }\end{array}$ & $\begin{array}{l}\text { Total number of } \\
10 \times 10 \mathrm{~km} \text { EAE } \\
\text { cells }\end{array}$ & $\begin{array}{c}\text { Number of } 10 \times 10 \mathrm{~km} \text { EAE cells } \\
\text { with at least one polecat } \\
\text { observation }\end{array}$ & $\%$ & $\begin{array}{c}\text { Number of } 10 \times 10 \mathrm{~km} \text { EAE cells } \\
\text { with at least one polecat } \\
\text { observation }\end{array}$ & $\%$ \\
\hline NORD-PAS-DE-CALAIS & 1 & 136 & 118 & $87 \%$ & 115 & $85 \%$ \\
\hline PICARDIE & 2 & 199 & 101 & $51 \%$ & 177 & $89 \%$ \\
\hline HAUTE-NORMANDIE & 3 & 127 & 46 & $36 \%$ & 117 & $92 \%$ \\
\hline BASSE-NORMANDIE & 4 & 181 & 76 & $42 \%$ & 181 & $100 \%$ \\
\hline ILE-DE-FRANCE & 5 & 119 & 47 & $39 \%$ & 110 & $92 \%$ \\
\hline CENTRE & 6 & 396 & 245 & $62 \%$ & 377 & $95 \%$ \\
\hline AUVERGNE & 7 & 263 & 150 & $57 \%$ & 252 & $96 \%$ \\
\hline LIMOUSIN & 8 & 174 & 83 & $48 \%$ & 170 & $98 \%$ \\
\hline BOURGOGNE & 9 & 318 & 189 & $59 \%$ & 279 & $88 \%$ \\
\hline FRANCHE-COMTE & 10 & 172 & 96 & $56 \%$ & 146 & $85 \%$ \\
\hline LORRAINE & 11 & 243 & 136 & $56 \%$ & 205 & $84 \%$ \\
\hline ALSACE & 12 & 86 & 60 & $70 \%$ & 59 & $69 \%$ \\
\hline CHAMPAGNE-ARDENNE & 13 & 258 & 128 & $50 \%$ & 244 & $95 \%$ \\
\hline RHONE-ALPES & 14 & 449 & 99 & $22 \%$ & 273 & $61 \%$ \\
\hline PROVENCE-ALPES-COTE D'AZUR & 15 & 332 & 21 & $6 \%$ & 80 & $24 \%$ \\
\hline LANGUEDOC-ROUSSILLON & 16 & 281 & 71 & $25 \%$ & 239 & $85 \%$ \\
\hline MIDI-PYRENEES & 17 & 457 & 193 & $42 \%$ & 450 & $98 \%$ \\
\hline AQUITAINE & 18 & 426 & 178 & $42 \%$ & 424 & $100 \%$ \\
\hline POITOU-CHARENTES & 19 & 261 & 118 & $45 \%$ & 266 & $100 \%$ \\
\hline PAYS DE LA LOIRE & 20 & 329 & 229 & $70 \%$ & 349 & $100 \%$ \\
\hline BRETAGNE & 21 & 303 & 154 & $51 \%$ & 267 & $88 \%$ \\
\hline
\end{tabular}

Table 1. - Repartition by French region of the polecat observations collected by the National Hunting and Wildlife Agency officers between 2001 and 2010 and comparison to the results obtained from the 1998-1999 inquiries, on the $10 \times 10 \mathrm{~km}$ European agency for the environment grid.

Tabla 1. Reparto por región francesa de las observaciones de turón recogidas por los funcionarios de la Agencia Nacional de Caza y Fauna Salvaje de 2001 y 2010 y la comparación con los resultados obtenidos de las consultas 1998-99, en una cuadrícula de 10 km x 10 km de la Agencia Europea de Medio Ambient.

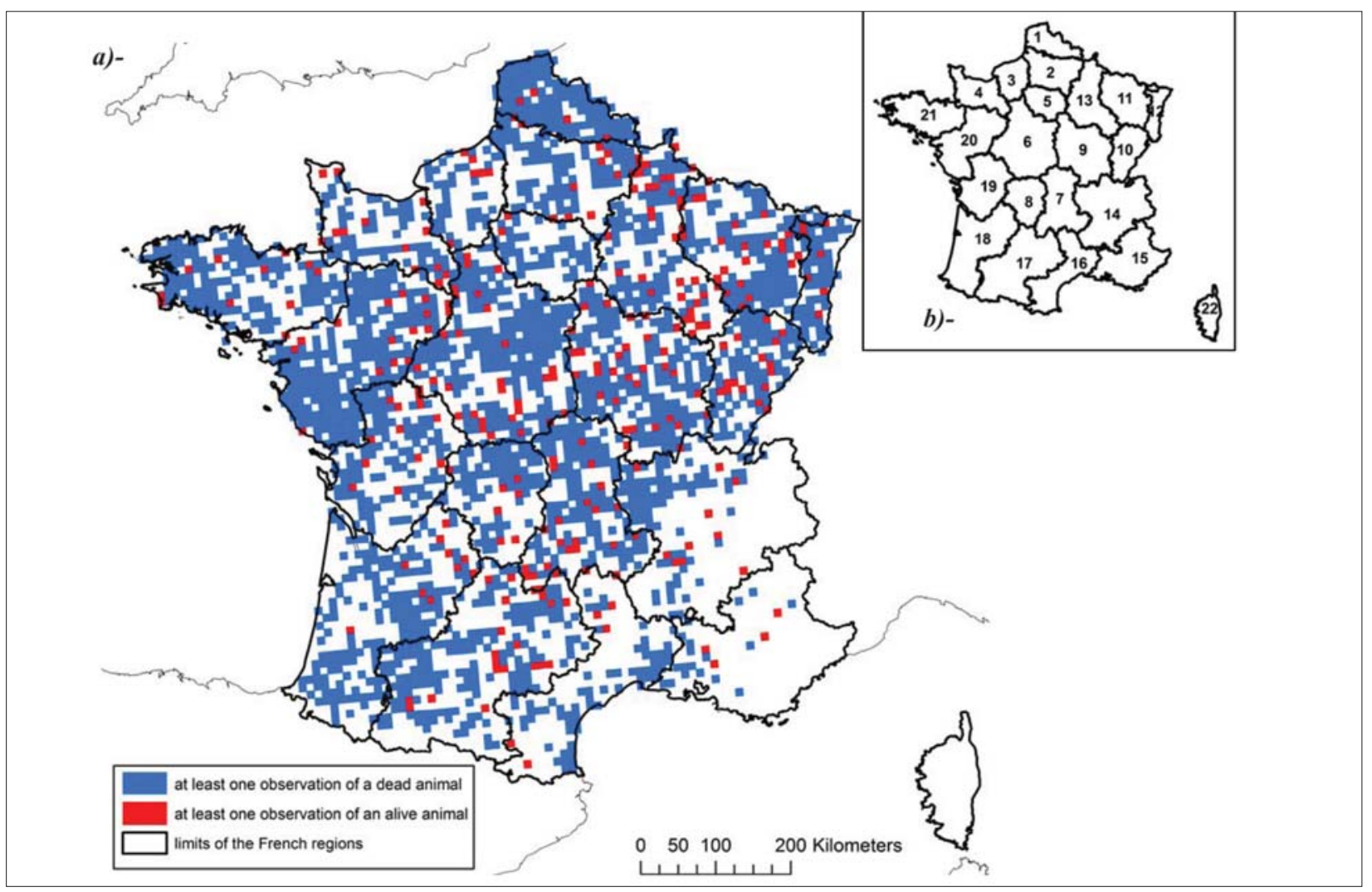

Fig. 1. - a)- Distribution of the observations of the polecat collected in France by the National Hunting and Wildlife Agency officers between 2001 and 2010 and reported on a grid of $10 \mathrm{~km} \times 10 \mathrm{~km}$ of the European agency for the environment. b)- Localisation of the French regions.

Fig. 1. - a)- Distribución de las observaciónes de turón recogidas en Francia por los funcionarios de la Agencia Nacional de Caza y Fauna Salvaje de 2001 y 2010 sobre una cuadrícula de 10 km x 10 km de la Agencia Europea de Medio Ambient. b)- Ubicación de las regiones francesas 
This map of presence of the species is globally similar with the first reference map available on the species (Roger et al., 1988, map available at http://inpn.mnhn.fr/espece/cd_nom/60731/tab/rep) based on the inquiries carried out more than 20 years ago (1983/1984), even if the number of observations was clearly lower. It is also comparable to results of the inquiries realized in 1998/1999 (Ruette et al., 2004, map available at http://carmen.carmencarto.fr/38/petits_carnivores.map) based on data gathered from the Departmental Associations of Trappers, the Departmental Federation of Hunters and the wildlife protection officers. In the second case, percents of cells with at least one polecat observation were higher varying between 24 and $100 \%$ with on average $85 \pm 23 \%$ per region (on the $10 \times 10 \mathrm{~km}$ EAE grid, Table 1). Differences in methodology between the inquiries exclude quantitative comparisons. However, whereas lowest percents were observed south-east France (regions 14, 15 and 16) in 1998/1999 as for the 2001-2010 period, observations were more frequent in south-west (regions 17 and 18).

\section{DISCUSSION}

The ONCFS notebook provides a valuable and cost effective tool to monitor the evolution of the presence of the species at a large scale. Species monitoring (Birks, 1997; Linnell et al., 2007; De Angelo et al., 2011; Virgos, 2003; Bonardi et al., 2011) or biodiversity monitoring (Foster-Smith \& Evans, 2003; Schmeller et al., 2008) on large scale often rely on volunteers involvement to assess populations trends. These methods have proven to be reliable as soon as volunteers have been trained enough and appropriately to species recognition or specific techniques (Newman et al., 2003; Foster-Smith \& Evans 2003). The notebook implementation by professional officers allows collecting data in real time rather than using the memory of the observers, a limit often encountered in surveys of distribution. However, when regarding all the data collected for all species, it is also obvious that some differences in the numbers of observations collected are not only linked to the species densities but also to the observers' motivation and to the heterogeneity of the road network between regions. We could not control for these biases but advocated that they are minimal when compared to volunteers-based inquiries.

Various limits should be pointed out regarding the result of the species distribution. As often, the lack of observations in a region does not indicate that the species is absent from the region, but simply that no observation was reported. In addition, although the number of new localities with at least one observation tends to increase since the implementation of the method (Ruette et al., 2008), the number of observations is still low and confirm the small probability of observation of the species, especially when compared to other species e.g. the badger or the stone marten. Whether this indicates a very low density or an inherent elusive behavior of the species is an important point that the method cannot address. Whatever the issue, this tool is only intended to monitor the species distribution at 5 to 10 years intervals, so that only major modifications of the species distribution could be detected.

Polecat observations were collected in all regions in France except in Corsica. The total number of observations was lower than in the 1998-1999 inquiries and far more numerous that in 1983-1984. Comparisons are limited because the methods used were clearly different between inquiries. However, following the scarce and irregular presence of the species in south-east France mentioned for more than 30 years, observations collected were rare in this region. Results in south-west France were more surprising and stressed the need for further studies to assess the presence of the species. Several methods have been used to estimate presence of carnivores (Kelly et al., 2012), such as small mustelids using molecular census (Riddle et al., 2003; Colli et al., 2005; Rosellini et al., 2008), spraint surveys (Reuther et al., 2000) or for larger species, tracks counting (Linnell et al., 2007) or camera trapping (Karanth, 1995; Blanc et al., 2012; Tobler et al., 2012). However, all have been developed at a small spatial-scale and cannot be easily undertaken at a national or regional scale. The results obtained at the national scale could be advantageously used to define priority regions where such studies should be undertaken.

Several threats and factors could explain the current distribution and trends observed since the 80's. The polecat is a species vulnerable to trapping. It had almost disappeared from Britain due to intensive trapping in the 50s (Langley \& Yalden, 1977). However, this species recolonized the country following the cessation of this practice (Birks \& Kitchener, 1999; Birks, 2000) and the increase of rabbit populations (Birks, 2000). In France, the polecat can be legally hunted and could be destroyed by trapping. Since August the 2nd 2012, the French legislation about "pest" species has been modified and, for 3 years, the polecat cannot be killed and trapped in France anymore. The species was classified as "pest" in half of French departments in 1997, 1999 and 2001. However, the intensity of trapping in France seemed to be limited: in 1998 , catches were performed on only $8.6 \%( \pm 14 \%)$ of localities where the species could be trapped (Ruette et al., 2004). Thus, trapping does not appear nowadays as a major threat for the species in France. However, trapping is still legally possible in France on other mustelid species and non selective predator control (Treves \& Naughton-Treves, 2005) could represent a threat for the polecat. For example, the American mink is now classified as an invasive species and can be killed or trapped all over the country. Confusion between both species may exist, particularly for the dark phenotype of polecat, whose facial mask is almost invisible (Fig. 2) and which presents a morphological convergence with the American mink and the European mink (Lodé, 1995). Some polecats may thus be eliminated by mistake. The training of trappers is therefore an essential measure where these mustelids, as well as the European mink, are present to avoid any misidentification. Beyond trapping, these species can also be subject to secondary poisoning that is le- 


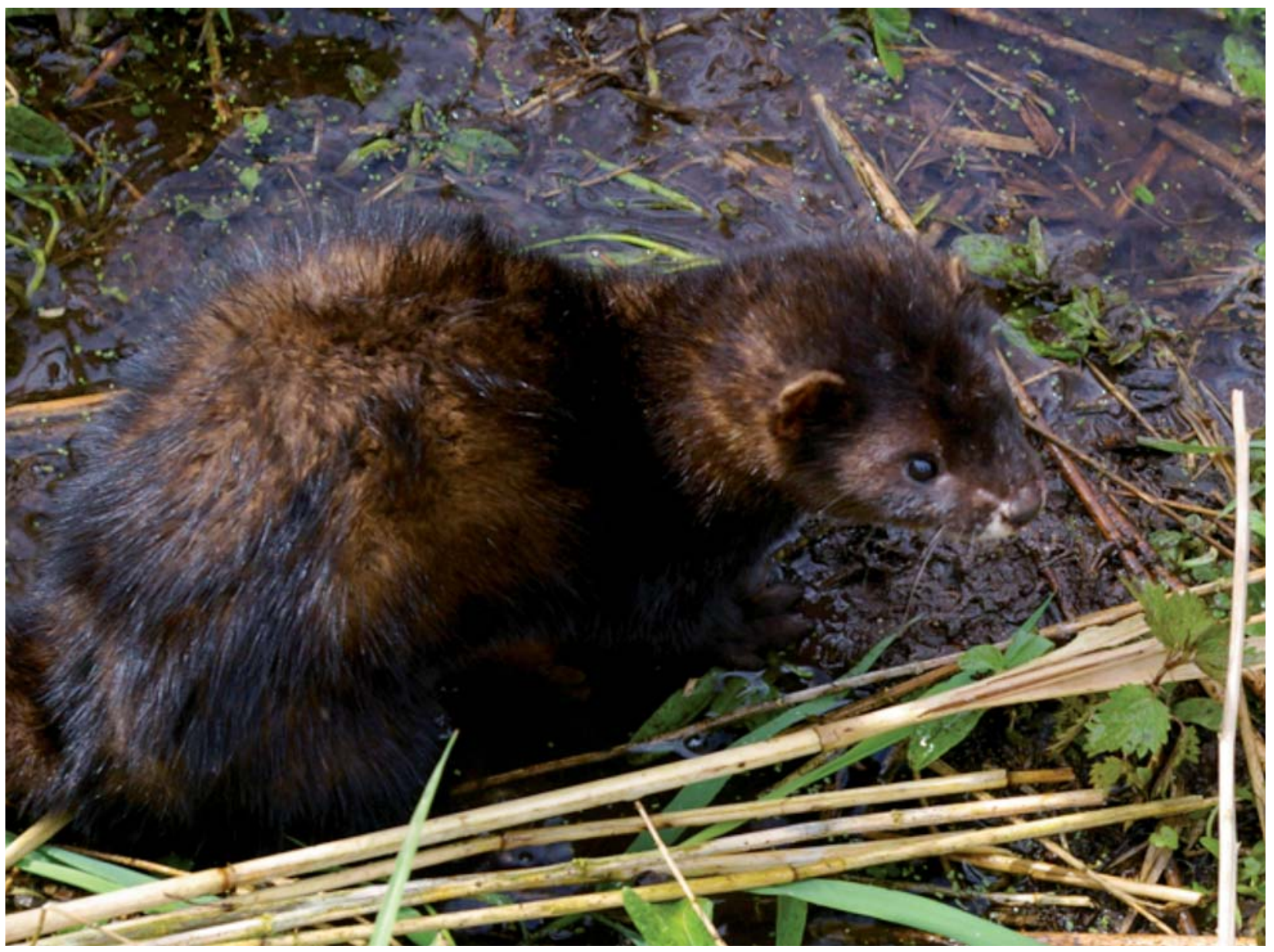

Fig. 2. - The dark polecat is characterized by an absence of facial mask.

Fig. 2. - El turón oscuro se caracteriza por la ausencia de la máscara facial.

gally used to control rodent (Fournier-Chambrillon, 2004; Giraudoux et al., 2006).

Recolonization of part of its territory in Britain suggests that the polecat has a good capacity for recolonization depending on factors such as availability of food resources and habitat (Birks, 2000). However, these two parameters, closely related, are subject to strong temporal fluctuations and changes. In France, the drying of wetlands and the increase of agricultural land have dramatically reduced wetlands areas in more than half between 1940 and 1990 (Report Claude Bernard 1994). In areas where the polecat preferably uses this kind of habitat, this reduction is particularly damaging in autumn and winter, during periods of lower abundance of amphibians that constitute one of its main prey (Weber, 1989a; Lodé, 1991; Baghli et al., 2002).

In the hedged farmland, the presence and abundance of polecats seem related to the presence of the rabbit and the importance of hedges providing adequate cover for displacement (Birks, 2000). Consequently, the leveling of the slope and the destruction of hedgerows could contribute to the decline of the species, impacting habitat as the one of its prey. Indeed, despite a slowdown in the uprooting of hedgerows since the 1990s, the surfaces of hedgerows have declined by $5 \%$ per year from 1982 to 1990 (Pointereau, 2002).

In the French Mediterranean region, the observations of polecat are much less frequent and its presence seems linked to the presence of wetlands that corroborates the results of Rondinini et al. (2006) and Mestre et al. (2007), respectively in Italy and Portugal. In these areas, the polecat is specialized in the predation on lagomorphs (Roger, 1991; Santos et al., 2009). However, rabbit populations are in steep decline for 25 years because of illness, such as the myxomatosis (Calvete et al., 1997) or the rabbit haemorrhagic disease (RHD) (Delibes-Mateos et al., 2009; Moreno et al., 2007), modification of its habitat and hunting (Calvete et al., 2006). Restocking operations are trying to rebuild these populations particularly in the Mediterranean region (Letty et al., 2006), but methods need to be improved (Calvete et al., 1997; Moreno et al., 2007). These transactions may prove beneficial in maintaining the polecat (Birks, 2000).

Last, the increase in the road network is another threat affecting polecats, as small carnivores in general. Mustelids are indeed described as vulnerable to traffic 
(Birks, 1993; Birks, 1997) and the density of the network can be a barrier to their expansion (Birks \& Kitchener, 1999). Moreover, the presence of prey near roads may also increase its traffic collision mortality (Birks, 1993; Barrientos \& Bolonio, 2008).

To fill the gap on the species knowledge, particularly in the regions where the density of polecat is low, studies at a finer scale, based on GIS modeling methods (Gough \& Rushton, 2000; Zabala et al., 2005; Mestre et al., 2007) would better determine its situation. Analysis of habitat parameters (area of wetlands and hedged farmland, and network traffic) and their evolution, in relation with the presence of the species are needed to better understand the influence of these parameters on the abundance and distribution of the polecat. Thus, local or regional management and conservation measures locally adapted could be implemented to reduce the impact of anthropogenic factors unfavorable to the species. In France, this kind of measure is partially implemented through the documents of objectives Natura 2000. This tool for management and conservation of habitats, including wetlands, could benefit the maintenance and preservation of this species. Moreover, national policy implementation of green and blue network will likely favor polecat which lives at the water / land interface.

The phenomenon of hybridization between polecats and domestic ferrets in Britain (Davison et al., 1999; Birks \& Kitchener, 1999) has fortunately not yet been described in France. However, few hybridization cases have been reported between polecats and European mink in France (Lode et al., 2005) and Eastern Europe (Maran \& Raudsepp, 1994; Tumanov \& Abramov, 2002). These observations are very punctual and the phenomenon is now more damaging to European mink populations than polecat population.

Finally, the dynamics of populations is poorly known and the parameters needed to estimate population viability, e.g. age-class survivals and reproduction parameters.

\section{CONCLUSIONS}

Even if the distribution of the species at the national scale is not alarming, so that the polecat is not considered threatened in France, nor Europe, its habitat is more and more fragmented (Baghli \& Verhagen, 2003; Santos-Reis, 1983; Roger et al., 1988). On a finer scale, the status of the polecat is still uncertain. Further studies, particularly in the Mediterranean and south-west regions where observations are scarce, would enhance results from the analysis. In France, the rehabilitation of wetlands, studies on the impact of roads on mortality of small carnivores, the trappers training in the recognition of mustelids, the restocking of rabbits are all measures that allow the maintenance, and even could improve the situation of the polecat in France. Public policies (Natura 2000, blue and green network) that contribute to the maintenance of biodiversity represent essential and useful tools for the conservation of wildlife (Donald et al., 2007).
Beyond these applied aspects, studies on population dynamics would provide knowledge relevant to the implementation of management measures. Maintaining a watch on the evolution of its distribution, already assured by the implementation of the ONCFS notebook, is essential.

\section{ACKNOWLEDGEMENTS}

The authors wish to thank the national wildlife protection officers for their collaboration.

\section{BIBLIOGRAPHY}

Baghli, A., Engel, E., Verhagen, R. 2002. Feeding habits and trophic niche overlap of two sympatric Mustelidae, the polecat Mustela putorius and the beech marten Martes foina. Z. Jagdwiss. 48: $217-225$

Baghli, A., Verhagen, R. 2003. The distribution and status of the polecat Mustela putorius in Luxembourg. Mamm. Rev. 33: 57-68.

Baghli, A. 2003. Ecology of the polecat Mustela putorius, Linnaeus 1758 (Mammalia, Carnivore) in Luxembourg. PhD thesis. University of Antwerpen. Antwerp.

Balme, G.A., Hunter, L.T.B., Slotow, R. 2003. Evaluating methods for counting cryptic carnivores. J. Wildl. Manag. 73: 433-441.

Barea-Azcon, J.M., Virgos, E., Ballestros-Duperon, E., Moleon, M., Chirosa, M. 2007. Surveying carnivores at large spatial scales: a comparison of four broad-applied methods. Biodivers. Conserv. 16: 1213-1230.

Barrientos, R., Bolonio, L. 2008. The presence of rabbits adjacent to roads increases polecat road mortality. Biodivers. Conserv. 18: 405-418

Birks, J.D.S. 1993. The return of the polecat. Br. Wildl. 5: 16-25.

Birks, J.D.S. 1997. A volunteer-based system for sampling variations in the abundance of polecats (Mustela putorius). J. Zool. 243: 857-863.

Birks, J.D.S. 1998. Secondary poisoning risk arising from winter farmyard used by the European polecat Mustela putorius. Biol. Conserv. 85: 233-240.

Birks, J.D.S. 2000. The recovery of the polecat, Mustela putorius, in Britain. In: Mustelids in a modern world - Management and conservation aspects of Small carnivore: human interactions. H.I. Griffiths (Ed.): 141-152. Backhuys Publishers. Leiden, The Netherlands.

Birks, J.D.S. Kitchener, A.C. 1999. The distribution and status of the polecat Mustela putorius in Britain in 1990s. The Vincent Wildlife Trust. London.

Blanc, L., Marboutin, E., Gatti, S. Gimenez, O. 2013. Abundance of rare and elusive species: empirical investigation of closed versus spatially explicit capture-recapture models with lynx as a case study. J. Wildl. Manag. 77(2): 372-378.

Bonardi, A. Manenti, R. Corbetta, A. Ferri, V., Fiacchini, D., Giovine, G., Macchi, S., Romanazzi, E., Soccini, C., Bottoni, L., Padoa-Schioppa, E., Ficetola, G.F. 2011. Usefulness of volunteer data to measure the large scale decline of « common » toad populations. Biol. Conserv. 144: 2328-2334.

Bright, P.W. 2000. Lessons from lean beasts: conservation biology of the Mustelids. Mamm. Rev. 30: 217-226.

Calvete, C., Villafuerte, R., Lucientes, J., Oscar, J.J. 1997. Effectiveness of traditional wild rabbit restocking in Spain. J. Zool. 241: $271-277$ 
Calvete, C., Pelayo, E., Sampietro, J. 2006. Habitat factors related to wild rabbit population trends after the initial impact of rabbit haemorrhagic disease. Wildl. Res. 33: 467-474.

Colli, L., Cannas, R., Deiana, A.M., Gandolfi, G. Tagliavini, J. 2005. Identification of mustelids (Carnivora: Mustelidae) by mitochondrial DNA markers. Mamm. Biol. 70: 384-389.

Davison, A., Birks, J.D.S., Griffiths, H.I., Kitchener, A.C., Biggins, D., Butlin, R.K. 1999. Hybridization and the phylogenetic relationship between polecats and domestic ferrets in Britain. Biol. Conserv. 87: 155-161.

Delibes-Mateos, M., Ferreras, P. Villafuerte, R. 2009. European rabbit population trends and associated factors: a review of the situation in the Iberian Peninsula. Mamm. Rev. 39: 24-140.

Donald, P.F., Sanderson, F.J., Burfield, I.J., Bierman, S.M., Gregory, R.D., Waliczky, Z. 2007. International conservation policy delivers benefits for birds in Europe. Science 317: 810-813.

Fournier-Chambrillon, C., Berny, P.J., Coiffier, O., Barbedienne, P., Dassé, B., Delas, G., Galineau, H., Mazet, A., Pouzenc, P., Rosoux, R., Fournier, P. 2004. Evidence of secondary poisoning of free-ranging riparian mustelids by anticoagulant rodenticides in France: implications for conservation of European mink (Mustela lutreola). J. Wildl. Dis. 40: 688-695.

Gompper, M.E., Kays, R.W., Ray, J.C., Lapoint, S.D., Bogan, D.A., Cryan, J.R. 2006. A comparison of noninvasive techniques to survey carnivores communities in Northeastern North America. Wildl. Soc. B. 34: 1142-1151.

Gough, M.C., Rushton, S.P. 2000. The application of GIS-modelling to mustelid landscape ecology. Mam. Rev. 30: 197-216.

Gros, P.M. Kelly, M.J., Cato, T.M. 1996. Estimating carnivore densities for conservation purposes: indirect methods compared to baseline demographic data. Oikos 77: 197-206.

Gros, P.M. 1998. Status of the cheetah Acinonyx jubatus in Kenya: a field-interview assessment. Biol. Conserv. 85: 137-149.

Gros, P.M. 2002. The status and conservation of the cheetah Acinonyx jubatus in Tanzania. Biol. Conserv. 106: 177-185.

Karanth, K.U. 1995. Estimating tiger Panthera tigris populations from camera-trap data using capture-recapture models. Biol. Conserv. 71: 333-338.

Kelly, M.J. Betsch J., Wultsch, C., Mesa, B., Mills, S. 2012. Noninvasive sampling for carnivores. In: Carnivore ecology and conservation, a handbook of techniques. L. Boitani, R.A. Powell (Ed.): 47-69. Oxford University Press. New York.

Langley, P.J.W., Yalden, D.W. 1977. The decline of the rarer carnivores in Great Britain during the nineteenth century. Mamm. Rev. 7: 95-116.

Letty, J., Aubineau, J., Berger, F., Marchandeau, S. 2006. Repeuplements de lapins de garenne: enseignements des suivis par radio-pistage. Faune Sauvage 274: 76-88.

Linnell, J.D.C., Fiske, P., Herfindal, I., Odden, J., Broseth, H., Andersen, R. 2007. An evaluation of structured snow-track surveys to monitor Eurasian lynx Lynx lynx populations. Wildl. Biol. 13: 456-466.

Lodé, T. 1991. Evolution annuelle du régime alimentaire du putois en fonction de la disponibilité des proies. Bull. Ecol. 22: 337-342.

Lodé, T. 1993. Stratégies d'utilisation de l'espace chez le putois européen dans l'Ouest de la France. Rev. Ecol. Terre Vie. 48: 305-322.

Lodé, T. 1994. Environmental factors influencing habitat exploitation by the polecat M.putorius in western France. J. Zool. 234: 75-88.
Lodé, T. 1995. Convergences morphologiques du putois (Mustela putorius) et du vison américain (M. vison) avec le vison d'Europe (M. Iutreola). Gibier Faune Sauvage. 12: 147-158. Disponible en web: http://storage.canalblog.com/18/05/451329/51904605.pdf.

Lodé, T. 1996. Conspecific tolerance and sexual segregation in the use of space and habitats in the European polecat. Acta Theriol. 41: 171-176.

Lodé, T. 1999. Time budget as related to feeding tactics of European polecat. Behav. Process. 47: 11-18.

Lodé, T., Guiral, G., Peltier, D. 2005. European mink-polecat hybridization events: hazards from natural process? J. Hered. 96: 1-8.

Long, R.A., Donovan, T.M., Zielinski, W.J., Buzas, J.S. 2007. Comparing scat detection dogs, cameras, and hair snares for surveying carnivores. J. Wildl. Manag. 71: 2018-2025

Maffei, L., Noss, A. J., Cuellar, E., Rumiz, D. I. 2005. Ocelot (Felis pardalis) population densities, activity, and ranging behaviour in the dry forests of eastern Bolivia: data from camera trapping. J. Trop. Ecol. 21: 1-6.

Maran, T., Raudsepp, T. 1994. Hybrids between the European mink and the European polecat in the wild - Is it a phenomenon concurring with the European mink decline? Second North European symposium on the ecology of the Small and mediumsized carnivores. Lammi, Finland. 8-11 April 1994.

Mestre, F.M., Ferreira, J.P., Mira, A. 2007. Modelling the distribution of the European polecat Mustela putorius in a Mediterranean agricultural landscape. Rev. Ecol., Terre Vie 62: 35-47.

Moreno, S., Beltran, J.F., Cotilla, I., Kuffner, B., Laffite, R., Jordan, G., Ayala, J., Quintero, C., Jimenez, A., Castro, F., Cabezas, S., Villafuerte, R. 2007. Long-term decline of the European wild rabbit (Oryctolagus cuniculus) in south-western Spain. Wildlife Res. 34: 652-658.

Pointereau, P. 2002. Les haies, évolution du linéaire en France depuis quarante ans. Le Courr. Environ. I'INRA. 46: 69-73.

Reuther C. Dolch, D. Green, R., Jahrl, J. Jefferies, D.J., Krekemeyer, A., Kucerova, M., Madsen, A.B., Romanowski, J., Roche, K., Ruiz-Olmo, J., Teubner, J., Trindade, A. 2000. Surveying and monitoring distribution and population trends of the Eurasian otter (Lutra lutra): Guidelines and evaluation of the standard method for surveys as recommended by the European section of the IUCN/SSC Otter Specialist Group. Habitat 12: 1-152.

Riddle, A.E., Pilgrim, K.L., Mills, L.S., McKelvey, K.S., Ruggerio, L.F. 2003. Identification of mustelids using mitochondrial DNA and noninvasive sampling. Conserv. Genet. 4: 241-243.

Roger, M. 1991. Régime et disponibilités alimentaires chez le putois (Mustela putorius L.) Rev. Ecol. Terre Vie 46: 245-261.

Roger, M., Delattre, P., Herrenschmidt, V. 1988. Le Putois (Mustela putorius Linnaeus, 1758). Encyclopédie des carnivores de France. Société Française pour l'Etude et la Protection des Mammifères. France.

Rondinini, C., Ercoli V., Boitani, L. 2006. Habitat use and préférence by polecats (Mustela putorius L.) in a Mediterranean agricultural landscape. J. Zool. 269: 213-219.

Rosellini, S. Osorio, E., Ruiz-Gonzales, A., Pineiro, A. Baria, I. 2008. Monitoring the small-scale distribution of sympatric European pine martens (Martes martes) and stone martens (Martes foina): a multievidence approach using faecal DNA analysis and camera-traps. Wildl. Res. 35: 434-440.

Ruette, S., Léger, F., Albaret, M., Stahl, P., Migot, P., Landry, P. 2004. Enquête sur la répartition de la martre, de la fouine, de la belette, de l'hermine et du putois en France. Faune Sauvag. 263: 28-34. 
Ruette, S., Albaret, M., Vandel, J.M., Léger, F. 2008. Suivi des petits carnivores en France-Analyse des données des carnets de bord récoltées entre 2001 et 2005 par les Services départementaux de l'ONCFS. Office National de la Chasse et de la Faune Sauvage. Auffargis.

Santois-Reis, M. 1983. Status and distribution of the Portuguese Mustelids. Acta Zool. Fennica. 174: 213-216.

Santos, M.J., Matos, H.M., Baltazar, C. Grilo, C., Santos-Reis, M. 2009. Is polecat (Mustela putorius) affected by «mediterraneity»? Mamm. Biol. 74: 448-455.

Schaller, G.B. 1996. Introduction: carnivores and conservation biology. In: Carnivore behavior, ecology, and evolution, vol. 2. J.L. Gittleman (Ed.): 1-10. Cornell University Press. Ithaca.

Sewell, D., Beebee, T.J.C., Griffiths, R.A. 2010. Optimising biodiversity assessments by volunteers: the application of occupancy modelling to large-scale amphibian surveys. Biol. Conserv. 143: 2102-2110.

Shore, R.F., Birks, J.D.S., Freestone, P., Kitchener, A.C. 1996. Second-generation rodenticides and polecats (Mustela putorius) in Britain. Environ. Pollut. 91: 279-282.

Shore, R.F., Birks, J.D.S., Freestone, P. 1999. Exposure of nontarget vertebrates to second-generation rodenticides in Britain, with particular reference to the polecat Mustela putorius, New Zeal. J. Ecol. 23: 199-206.

Shore, R.F., Birks, J.D.S., Afsar, A., Wienburg, C.L., Kitchener A.C. 2003. Spatial and temporal analysis of second-generation anticoagulant rodenticide residues in polecats (Mustela putorius) from throughout their range in Britain, 1992-1999. Environ. Pollut. 122: 183-193.
Stahl, P., Léger, F., Migot, P. 1997. Répartition des petits carnivores en France. Bibliographie et recommandations pour la poursuite du recueil des informations. Office National de la Chasse - CNERA Prédateurs et animaux déprédateurs, en collaboration avec le Service du patrimoine naturel du Muséum National d'Histoire Naturelle. Paris.

Tobler, M.W., Powell, G.V.N. 2012. Estimating jaguar density with camera traps: problems with current designs and recommandationsns for future studies. Biol. Conserv. 159: 109-118.

Treves, A., Naughton-Treves L., 2005. Evaluating non-lethal control in the management of human-wildlife conflict. In: People and wildlife: conflict or coexistence. R. Woodroffe, S. Thirgood, A. Rabinowitz (Ed.): 86-106. Cambridge University Press. Cambridge.

Tumanov, I.L., Abramov, A.V. 2002. A study of the hybrids between European mink Mustela lutreola and the polecat M. putorius. Small Carniv. Conserv. 27: 29-31.

Weber, D. 1989a. The diet of polecats (Mustela putorius L.) in Switzerland. Z. Säugetierkd. 54: 157-171.

Zabala, J., Zuberogoitia, I., Martinez-Climent, J.A. 2005. Site and landscape features ruling the habitat use and occupancy of the polecat (Mustela putorius) in a low density area: a multiscale approach. Eur. J. Wild. Res. 51: 157-162. 